nużącego - szczególnie dla młodszych uczniów - przepisywania książek, ciagła rotacja nauczycieli, która sprawiała, że nawet najzdolniejsi wykładowcy trafiali często po jednym przeprowadzonym kursie do administracji zakonnej, schlebianie utylitarnym gustom szlachty, powodujące obniżenie poziomu nauczania i rugowanie abstrakcyjnych, subtelnych pól rzeczywistości, czy nadmierne akcentowanie współzawodnictwa mogły stanowić przedmiot poważnej krytyki szkolnictwa jezuitów. Niestety większość zarzutów, z jakimi się spotykamy w literaturze, jest tylko powtórzeniem obelg zawartych w dawnych pamfletach lub kopią skrajnych uproszczeń oświeconej dziewiętnastowiecznej propagandy.

Tymczasem jeden z polskich szermierzy racjonalizmu, ten sam, który niemało przyczynił się do powstania czarnego mitu Towarzystwa, przyznawał: „Obszerniejszego wyobrażenia o stanie akademii wileńskiej i wszystkich innych jezuickich szkołach, dać nie umiem, ponieważ ani akademii wileńskiej, ani sławniejszych kolegiów jezuickich w Koronie osobiście nie znałem" ${ }^{35}$.

Katarzyna Kabacińska

Poznań

\title{
Zabawy i zabawki dziecięce w pismach Lukasza Gołębiowskiego
}

Któż z nas, dorosłych, nie patrzy z sentymentem na pluszowego misia, niekiedy z szyta łapką, przyklejonym oczkiem, szmacianą lalkę, drewnianego konika na biegunach, domek dla lalek, naszą pierwsza żelazną kolejka? W tych przedmiotach kryje się jakaś magia innego, odległego, radosnego ale przede wszystkim lepszego świata. To właśnie ów szary miś był powiernikiem naszych kłopotów, przytulaliśmy się do niego, gdy czuliśmy, że nikt nas nie rozumie. I choć właściwie okres dzieciństwa przebiega na zabawie, wszystko zależy od tego, jak poprzez zabawę wchodzimy do świata dorosłego, poznajemy siebie i staramy się zrozumieć życie. Ten tajemniczy świat naszego dzieciństwa minął bezpowrotnie, ale pozostały wspomnienia zabaw, żartów, będących radością i szczęściem tamtych dni. Teraz, po latach, staramy się nauczyć nasze dzieci wyliczanek, rymowanek, figlików, zabaw, w które bawiły się $z$ nami nasze mamy, mamki, babcie. $W$ ten sposób, przekazywane $z$ pokolenia na pokolenie, trwają w świadomości narodu najstarsze igraszki i zabawki.

Ale zabawa nie jest znamienita cechą tylko dzieciństwa. Ludzie bawili się zawsze i wszędzie. Niezależnie od wieku, płci, wyznania, przynależności klasowej, pozycji spolecznej, miejsca i czasu. Podejmując rozważania na temat szeroko rozumianej zabawy, nie należy ujmować jej w oderwaniu od grupy społecznej, gdyż, jak twierdzi T. Paleczny: „każda zbiorowość (...) wytwarza właściwe tylko sobie, oryginalne i niepowtarzalne formy zabawy - rozrywki”!' Trzeba jednak dodać, iż „zabawy i zabawki podobnie jak twórczość artystyczna i dzieła sztuki odsłaniaja, przede wszystkim, intymność biograficzna ich twórców, a przez różne formy akceptacji w trakcie trwania aktów kreacyjnych (również zabawowych) daja świadectwo o bawiących się użytkownikach i twórcach"2 . Zabawa, będąca nie tylko dowodem indywidualnych cech osobowościowych jej uczestników, ale także posiadająca

\footnotetext{
${ }^{35}$ H. Kolłaltaj, op. cit., s. 108.

'T. Paleczny, Spoleczne podloze zabawy, w: „Zabawy i Zabawki” 1997, nr 1-2, s. 20.

${ }^{2}$ R. Zięzio, Wokót naczelnej zasady funkcjonalnej w zachowaniach ludycznych, w: „Zabawy i Zabawki" 1997 ,
} nr 3, s. 9 . 
„społeczny sens i grupowy charakter" ${ }^{3}$, podobnie jak wiele innych zjawisk kulturowych, stwarza „ogromne trudności w jej adekwatnym - ze względu na konstytuujące ja różnorodne elementy i cechy - teoretycznym ujęciu" 4 .

Problematyka zabaw jest kwestią wieloaspektowa. B. Sułkowski, socjolog, trafnie zauważył, iż: „próba uchwycenia istoty zabawy pokazała teoretyczną złożoność zjawiska"s. Ustalenia definicyjne, określenie funkcji i celów zabawy, sprawiaja teoretykom kultury, psychologom, socjologom, pedagogom, etnologom, archeologom wiele trudności.

Problematyka zabaw była poruszana przez badaczy pod wieloma względami. Holenderski historyk kultury J. Huizinga, w swoim wiekopomnym dziele z 1938 roku Homo ludens, definiuje zabawę w następujący sposób: „Zabawa jest dobrowolną czynnością lub zajęciem, dokonywanym w pewnych ustalonych granicach czasu i przestrzeni wedlug dobrowolnie przyjętych, lecz bezwanunkowo obowiazujacych reguł, jest celem samym w sobie, towarzyszy jej zaś uczucie napięcia i radości i świadomość

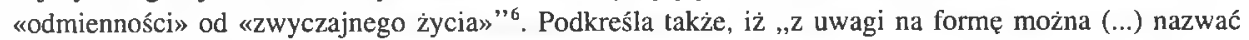
zabawę czynnością swobodna, którą odczuwa się jako «nie tak pomyślaną» i pozostajaca poza zwykłym życiem"7. Dodaje również, iż nakazana zabawa nie jest już zabawą. Natomiast R. Callois definicję Huizingi uściśla stwierdzając, iż „reguła nie jest koniecznym czynnikiem każdej zabawy" A. Zadrożyńska wykorzystując ujęcie Huizingi i komentarz jego koncepcji autorstwa R. Calloisa w eseju pt. Żywioł $i$ tad, starała się ukazać związek między pracą a świętem, twierdząc, że „zabawa jest formą nie-pracy"9. Porównała człowieka pracy i człowieka bawiącego się ujmując zarówno homo faber, jak i homo ludens w modelu tradycyjnym, przejściowym i współczesnym. Aby w pełni określić interdyscyplinarne zainteresowanie problemami zabawy, należy pamiętać jeszcze o badaniach socjologicznych i pedagogicznych. Przedstawicielem tych pierwszych jest, cytowany już B. Sułkowski, który uważa iż: „,socjologiczne ujęcie zabawy sprowadza się do polaryzowania zabawy i pracy oraz umieszczenie tej pierwszej w perspektywie wolnego czasu" ${ }^{10}$. Tworzy on także pojęcie człowieka nie próżnującego, dla którego zabawa jest zajęciem bezinteresownym, będącym wypoczynkiem dla ludzi pracujących. Autor konkluduje, iż w badaniach „obserwowano przenikanie się postaw ludzkich w zabawie i w życiu serio" ${ }^{11}$. W. Okoń, przedstawiciel pedagogiki, ,pisząc o wielorakich, społecznych funkcjach zabawy, podkreśla szczególnie fakt, iż reprezentuje ona niezwykłą rzeczywistość” ${ }^{2}$.

Jednoznaczne i pełne zdefiniowanie zabawy zdaje się być, mimo prób badaczy, kwestią nadal otwarta. Fakt ten wynika przede wszystkim z wieloznaczności słowa „zabawa”. „Analizując dawna semantykę (...) zauważmy, iż w języku lacińskim wyrażeniem ludus oznaczano wszelką spontaniczną, niekontrolowaną i niezobowiązująca aktywność ruchowa, a więc żwawe poruszanie się, bieganie tu i tam, skakanie, owo dokazywanie, figlowanie, swawolenie, na co język staropolski miał swój odrębny termin igraszki (od igrac, igrca, igra). Ten sens odnajdujemy również we współczesnym polskim pojęciu zabawy, angielskim play, francuskim jeu, czy niemieckim Spiel"'13.

W badaniach naukowych problem zabaw i zabawek był traktowany jako temat ,niepoważny" i dlatego istnieje w nim, jak można rzec, posługujac się terminem teoretycznoliterackim, wiele niedookreślonych miejsc. „Zabawkarstwo, ta «niepoważna» dziedzina nauki i kultury, spełnia wiele bardzo istotnych funkcji społecznych. Na równi z innymi przejawami działalności ludzi tworzy trwałe dziedzictwo kulturalne, które mamy obowiązek rozwijać, chronić i badać” ${ }^{14}$. Niestety „pomimo zachęty

\footnotetext{
${ }^{3}$ T. Paleczny, op. cit., s. 20.

4. Grad, Zabawa - analiza pojęć i koncepcji, w: "Zabawy i Zabawki" 1997, nr 1-2, s. 7.

"B. Sułkowski, Zabawa. Studium socjologiczne, Warszawa 1983, s. 254.

6 J. Huizinga, Homo ludens, Warszawa 1998, s. 55-56.

7 J. Huizinga, Homo ludens, Warszawa 1998, s. 28.

${ }^{8}$ Za: B. Sułkowski, op. cit., s. 9.

${ }^{9}$ A. Zadrożyńska, Homo faber $i$ homo ludens, Warszawa 1983, s. 179.

${ }^{10}$ B. Sułkowski, op. cit., s. 5.

"Ibidem, s. 271.

12 Cyt. za: Ślaskie uciechy $i$ zabawy, materiaty etnologiczno-folklorystyczne, pod red. I. Bukowskiej-Floreńskiej, Bytom 1991, s. 12.

${ }^{13}$ J. Grad, op. cit., s. 8-9; por.: 3. Huizinga, op. cit., s. 58-76.
} 
ze strony wielu znawców zabawek (T. Seweryna, J. Bujaka i wielu innych) o zwiększenie zainteresowań badawczych, niewiele się zmieniło" I5. Z obszerniejszych tematycznie XX-wiecznych opracowań na uwage zasługuja między innymi pozycje: T. Seweryna, J. Bujaka, J. Cieślikowskiego, T. Lewińskiej ${ }^{16}$.

"To wlaśnie zabawki ludowe współtworza obraz wsi dawnej i współczesnej oraz małych miasteczek, gdzie są najczęściej wytwarzane i przez dziecięca zabawę nabywają wartości historycznej i artystycznej" 17 . Wiedza o ich genezie i funkcjach, o powiązaniu z obrzędowością, jak podkreślają sami badacze ${ }^{18}$, jest niewielka. XX-wieczni badacze często odwołują się do XIX-wiecznych pism naukowych. J.S. Bystroń we Wstepie do ludoznawstwa polskiego z roku 1926 pisał: „Wchodzimy w okres powszechnego zainteresowania się ludem. Z zapalczywej młodzieży jedni wędrowali po wsiach, zbierali tradycje ludu (...), inni siedzieli w bibliotekach. Do takich typów ksiażkowych należeli dwaj pisarze, którzy niegdyś mieli wielkie znaczenie w Kongresówce: Łukasz Gołębiowski i Kazimierz Wladysław Wójcicki" ${ }^{\prime 9}$. J.S. Bystroń w taki sposób charakteryzuje Ł. Gołębiowskiego: „Z zawodu bibliotekarz, bardzo pracowity, mało oryginalny i niekrytyczny, zwraca uwagę szerszych kół na badania historyczno-kulturalne; pierwsze to większe prace, poświęcone obyczajowości Polski ludowej i szlache-

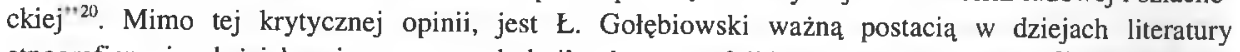
etnograficznej, gdyż jako pierwszy wyodrębnił zabawowy folklor dzieci i nastolatków ${ }^{21}$. P. Chmielowski w Metodyce historyi literatury polskiej z 1900 roku podkreśla, iż: „W znacznej części na podstawie notat Lelewela, Łukasz Gołębiowski ogłosił książkę pt. $O$ dziejopisach polskich, ich duchu, zaletach $i$ wadach (Warszawa 1826), która przez lat blisko 50 pozostała jedynym dziełem, skupiajacym w sobie całość historyi naszego dziejopisarstwa"22. Opinie współczesnych Gołębiowskiemu badaczy zawierają zarówno elementy krytyki, jak i słowa pochwały. Przykladem może być opinia K. W. Wójcickiego wyrażona na łamach „Tygodnika Ilustrowanego" z roku 1861: „Prace Golębiowskiego już dziś tej wartości nie maja, jaką okazywały w chwili wydania, bo też na tem polu zrobiliśmy wielkie postępy; lecz prace jego wyłącznie poświęcone starożytnościom krajowym, jakkolwiek już niedostateczne, rzuciły w naród masę wiadomości co do życia dawnego przodków naszych (...). Równie życiem całem, jak i ogromem prac swoich, zasługuje na wdzięczną u potomnych pamięć" 23 .

Gołębiowski urodzil się 13 października 1773 roku w Podhoście (niedaleko Pińska). Uczyl się najpierw $w$ domu - ojciec nauczył go czytać w języku polskim, ruskim i po łacinie. Przydało się młodemu Łukaszowi domowe wychowanie, którego celem było głównie ukształtowanie silnego charakteru, rozsądku oraz wielkiego serca, szczególnie w następnym etapie edukacji, jakim była nauka w szkole pijarów w Dabrowicy na Polesiu. Lata te upłynęly na pilnej nauce. Jako uczeń ostatniego roku zastępowal w konwikcie nauczyciela języka niemieckiego. Po zakończeniu nauki, za protekcja A. Felińskiego, przyjaciela z lat szkolnych, Łukasz otrzymał posadę jako kancelista u komisarza T. Czackiego. Kolejny etap w życiu Gołębiowskiego to tworzenie przez T. Czackiego biblioteki w Warszawie, a od 1792 roku w Szczekocinie. W pierwszych dniach powstania kościuszkowskiego, 24 marca 1794 roku, zaciagnął się do wojska i został przydzielony do kancelarii T. Kościuszki. Gołębiowski brał udział w bitwie pod Szczekocinami. Za udział w obronie Warszawy awansował na chorażego. Po upadku powstania przebywał w Jarosławiu w Galicji. Później wyjechał z T. Czackim na Wołyń. Od roku 1795 do 1818 przebywał w Porycku na Wołyniu jako bibliotekarz T. Czackiego

\footnotetext{
${ }^{14}$ T. Lewińska, Kolorowy swiat zabawek, Kielce 1995, s. 6.

15 Ibidem, s. 6.

16 T. Seweryn, Polskie zabawki ludowe, Warszawa 1960, J. Bujak, Zabawki w Europie, Kraków 1988,

J. Cieślikowski, Wielka zabawa, Wrocław 1985, T. Lewińska, Kolorowy swiat zabawek.

17 T. Lewińska, op. cit., s. 6.

${ }_{18}$ Por.: J. Bujak, op. cit., T. Lewińska, op. cit.

19 J. S. Bystroń, Wstep do ludoznawstwa polskiego, Lwów 1926, s. 80.

20 Ibidem, s. 80 .

${ }^{21}$ Wiadomości za: R. Waksmund, Dziecko w swietle polskiej etnografii i folklorystyki lod Kitowicza do Korczaka), w: „Literatura Ludowa" 1996, nr 4-5, s. 31.

${ }^{22}$ P. Chmielowski, Metodyka historyi literatury polskiej, Warszawa 1900, s. 227.

${ }^{23}$ K. W. Wójcicki, Lukasz Gotębiowski, w: „Tygodnik Ilustrowany" 1861, nr 91, s. 230.
} 
prowadząc jednocześnie jego kasę, rachunkowość i kancelarię. Poznał młodą, piętnastoletnią Józefę Pałucka i poślubił ja 26 czerwca 1803 roku. Podczas pobytu w Porycku uporządkował wówczas Bibliotekę Porycka, napisał „Przedmowę do rejestru Biblioteki Poryckiej” (1814), w której dał ciekawą charakterystykę samej biblioteki i jej twórcy ${ }^{24}$. W 1813 umarł T. Czacki. Gołębiowski pozostał jeszcze pięc lat w Porycku, aby wraz z księdzem L. Osińskim wydać nową edycję dzieł ${ }^{25}$. W 1818 roku wraz ze sprzedana Czartoryskim Biblioteka Porycka, przeniósł się do Puław, gdzie również objal stanowisko bibliotekarza $\mathrm{j}$ opiekuna zbiorów. Jednocześnie prowadzil gromadzenie odpisów z kilku archiwów zagranicznych. Na polecenie Izabeli Czartoryskiej opisał 200 rękopisów do niej należących oraz zbiór medali i pamiatki historyczne w Światyni Sybilli i Domku Gołyckim. W 1818 roku został czynnym członkiem Towarzystwa Przyjaciół Nauk. W latach 1818-1826 wydał w Wilnie 7-tomowy przekład powieści Barthelemy'ego pt. Podróze młodego Anarchazisa po Grecji. W 1823 roku przeniósł się do Warszawy i został mianowany czynnym członkiem Towarzystwa do Ksiąg Elementarnych. „Zadaniem Gołębiowskiego była ocena nadsyłanych przez autorów podręczników, jednocześnie sam opracował podręcznik do nauki historii" 26 . Około 1831 roku został mianowany bibliotekarzem Biblioteki Publicznej (później biblioteki Uniwersyteckiej) „z obowiazziem wykładania bibliografii na uniwersytecie" 27 . W 1826 roku zająl się głównie pracami naukowymi, opierajac się częściowo na notatkach J. Lelewela, opracował i wydał pierwszy przegląd całości historiografii polskiej, nie pozbawiony wartości informacyjnej, pt. $O$ dziejopisach Polski, ich duch, zaletach $i$ wadach ${ }^{28}$. Także w 1826 roku ukazało się dzieło pt.: Opisanie historyczno-statyczne miasta Warszawy - ,jedna z pierwszych książek poświęcona historii stolicy"29. Opracował pierwsze polskie dzieło etnograficzne, wydane w 1830 roku pt. Lud polski, jego zwyczaje $i$ zabawy. W tym też roku wydał Ubiory w Polsce, w 1831 roku ukazała się kolejna jego pozycja książowa pt.: Gry i zabawy różnych stanów. Po upadku powstania listopadowego, w wynıu represji popowstańczych, ucisku politycznego oraz problemów osobistych ${ }^{30}$, zakupił gospodarstwo i pozostał w nim do śmierci. Kaźmirówka stała się dla Gołębiowskiego ostoją spokoju i zadowolenia. W latach 1841-1843 ogłosił Gabinet medalów polskich. W latach 1846-1848 wydał 3-tomowe Dzieje Polski. 21 sierpnia 1844 zmarła w Lublinie żona Gołębiowskiego. Jej śmierć załamała go fizycznie i psychicznie. Zmarł 7 stycznia 1849 roku. Pochowany został w Gródku nad Bugiem, w grobie żony. Całe niemal swoje życie poświęcił żonie, rodzinie oraz pracy naukowej.

Mimo krytyki dzieł Gołębiowskiego, należy podkreślić pionierskość jego badań, szczególnie w dziedzinie literatury (zbiór tekstów literackich) oraz etnografii dotyczących wyodrębnienia folkJoru dziecięcego, opisu zwyczajów, zabaw ludu polskiego, ruskiego itp. Opisał je w 4 tomach:

1. Lud polski, jego zwyczaje $i$ zabawy, Warszawa 1830;

2. Ubiory w Polsce, Warszawa 1830;

3. Domy $i$ dwory, Warszawa 1830 ;

4. Gry $i$ zabawy różnych stanów, Warszawa 1831.

Zwyczaje, nierozerwalnie złaczone $\mathrm{z}$ szeroko rozumianym świętem ${ }^{31}$, niewatpliwie zawierały i zawieraja w sobie elementy zabawy. Pomijając trudności semantyczne, teoretyczne, klasyfikacyjne i aksjologiczne określenia zabawy, należy zwrócić uwagę na rozumienie jej przez Gołębiowskiego. Podkreśla on, że „szuka jej [zabawy] zarówno wiek dziecinny, średni i podeszły, nie odrzuca późna starość nawet; po trudach i pracy rozrywa się nią w swobodniejszej chwili, kmiotek, mieszczanin,

${ }^{24}$ Opisal 1558 folialów rękopisów i sporzadził ich regest liczący 1212 arkuszy.

${ }^{25}$ Do planowanego wydania nie doszło, gdyż pani Czacka oddała Platerowi rękopisy - ten ich nie wydał. Po wielu latach Golębiowski odzyskał rękopisy i oddał Czackiej.

${ }^{26}$ Polski Słownik Bibliograficzny, T. VIII, Kraków 1959-1960, s. 251.

${ }^{27}$ Ibidem, s. 251 .

${ }^{28}$ Ibidem, s. 251.

29 Ibidem, S. 251.

${ }^{30}$ W 1833 roku na rozkaz. Paskiewicza otrzymał dymisję ze stanowiska sekretarza Towarzystwa Przyjaciół Nauk, za ukrycie funduszów przed konfiskata rząu carskiego.

31 Por.: A. Zadrożyńska, op. cit. 
kupiec, szlachcic, pan możny, za nia się ubiega rycerz i prawnik, człowiek światowy i kaplan lub zakonnik, uczony i prostak, płeć jedna i druga, z tạ tylko różnica, że sobie właściwej szuka, tę wybiera, tej nad innemi daje pierwszeństwo" ${ }^{32} . \mathrm{Z}$ powodu wielości „i trudne ich wyliczenie, podział i opisanie trudne” 33 . Gołębiowski dostrzega także różnice miedzy grą i zabawą: „Niejedna zabawa w grę przechodzi, gdy się do niej pieniężna jakaś wartość przykłada, gdy się jakaś nagroda stanowi" ${ }^{34}$. Gołębiowski nie pozbyl się trudności typologizacyjnych. Jedynym kryterium, którego przestrzegał konsekwentnie było wyodrębnienie zabaw dla dzieci i mlodzieży w Grach $i$ zabawach. Zabawy dla dorosłych, zawarte w Grach $i$ zabawach oraz książce pt. Lud polski, nie sa pogrupowane dokładnie. W pierwszym piśmie przyjął zasadę układu alfabetycznego. W jego obrębie rozwinal między innymi gry, które podzielił na gry dziecięce (o nich dokładniej niżej), dla osób samotnych, dla dwóch lub więcej osób, gry hazardowe - tu głównie karty, gry kmiotków i niższych stanów, gry żydowskie, gry spoleczne średnich $\mathrm{i}$ wyższych klas, te $\mathrm{z}$ kolei na kilka rodzajów: między innymi z bieganiem, biciem połączone, umyslowe; łowy, muzykę. Głównymi źródłami „pisanymi”, na które powołuje się w Grach i zabawach, sa teksty między innymi: Ł. Gómickiego, M. Bielskiego, J. Kitowicza, J. Kochanowskiego, W. Potockiego, wspólczesne jemu czasopisma, między innymi Kurier Warszawski, teksty K. Brodzińskiego oraz nadesłany przez K. z Tańskich Hoffmanowa opis „60 rodzajów gier lub zabaw rozmaitych młodszego i dalszego wieku." ${ }^{35}$.

Gołębiowski w dwojaki sposób opisał w Grach $i$ zabawach zabawy dla dzieci i młodzieży. Pierwszy, pełniejszy to wyszczególniony opis zabaw i zabawek. Drugi, bẹdacy uzupełnieniem poprzedniego, to przedstawienie zabaw i zabawek przy charakterystyce zabaw dorosłych. Gołębiowski zwraca także uwagę, co trzeba podkreślić, na proweniencję niektórych zabaw dorosłych: „Podamy z kolei i te, które ze studenckich utworzyły się i przeszły w zabawy dorosłych, a czasem i wyższych osób" 36. Gołębiowski prezentuje także zabawy, w które bawili się zarówno dorośli, jak i dzieci.

Autor Gier i zabaw charakteryzując na wstępie gry dzieci, podaje ich funkcję: „Sa gry służące do rozwinięcia w młodzieży ciała, nadania jej ruchu, ożywienia, są równie spokojne, lecz zajmujące umysł, te poważniejszym właściwie; sa, które do rycerskiego sposobić maja rzemiosła, inne które prócz wesolości i rozśmieszenia żadnego nie zdaja się mieć innego celu. Tak obieraj, gdy chcesz być dobrym gospodarzem lub gospodynią, która właściwsza twemu społeczeństwu uznasz" ${ }^{37}$. Można tę refleksję porównać ze współcześnie określanymi funkcjami zabawy. XIX-wieczna rola zabaw wykazuje podobieństwa do funkcji zabaw w ujęciu np. Urszuli Kaczmarek, która stwierdza: „Gdybyśmy mieli wybrać najważniejsze funkcje, jakie spełnia zabawa - w moim przekonaniu - byłyby to:

a) funkcja biologiczna, bowiem zabawa upiększa życie, uzupełnia je, daje wytchnienie, regeneruje, daje odprężenie, wreszcie wywołuje śmiech;

b) funkcja kulturalna - sprzyja rozwojowi jednostki w poczuciu kultury i swoistego piękna;

c) funkcja społeczna - autoteliczna $z$ bezinteresownościa i dobrowolnością oraz instrumentalna zwiazana z nauka i wychowaniem tak dzieci, jak i dorosłych" ${ }^{38}$. Czyż Gołębiowski nie podkreślal funkcji instrumentalnej, choć jej tak oczywiście nie nazwał, mówiąc: „sa [gry], które do rycerskiego sposobić się mają rzemiosła" lub autotelicznej w słowach: „inne które prócz wesołości i rozśmieszania żadnego nie zdają się mieć innego celu"?

Golębiowski podzielił gry dzieci na: gry niemowlęce i dziecinne (scharakteryzował ich 18), gry „studentskie", te z kolei na dwa typy: gry nadajace ruch ciału (7), gry „,studentskie” uczace cierpliwości lub zręczności (5) oraz gry „studentskie” nierozsadne; gry dziewczatek małych (12), w których zwrócił uwage na zabawki.

32 Ł. Gołębiowski, Gry $i$ zabawy róznych stanów, Warszawa 1831, s. 5.

33 Ibidem, s. 5.

34 Ibidem, s. 5.

35 Ibidem, s. 7.

36 Ibidem, s. 14.

37 Ibidem, s. 5.

${ }^{38}$ U. Kaczmarek, Pedagogika zabawy - nowy styl wychowania, w: „Zabawy i Zabawki" 1997, nr 4, s. 7. 
Gołębiowski rozpoczynając charakterystykę gier niemowlęcych i dziecinnych, podkreśla rolę zabawy we wczesnym okresie życia dziecka: „Wiek ten tyle zajmuje, odkąd piastować zaczyna się dziecię, już przemyślaja o jego zabawie. Zabawa i płacz jego powściagga, i ból zdaje się uśmierzać, jakoż okazuje minką, że jeszcze jej pragnie" ${ }^{39}$. Stwierdza także, że już same mamki i piastunki wymyślaja zabawy lub „to maja $z$ dawniejszego podania"40. Akcentuje także rolę muzyki w wychowaniu dzieci, a szczególnie małych: „przyrodzenie mamki nauczyło śpiewac, aby śpiewaniem dziecinny płacz tuliły” 41 . Według niego wybór zabaw zależy od obyczajów: „,co kraj, co prowincja, co dom, to inny obyczaj" "22. Wśród wymienionych zabaw, gdy dziecko jest jeszcze w kolebce, przedstawia: „śpiewki przy kolebce, brząkanie kluczami, wydawanie dźwięku mokrym palcem wodząc po oknie, kręcenie naparstka, kluczyka, pieniądza, żeby się obracały młynkiem"43.

Wszystkie czynności podczas tych zabaw wykonywały mamki lub inne osoby dorosłe. Można je podzielić na: słowne, dźwiękowo-ruchowe i ruchowe.

Słowne - obejmują wszelkiego rodzaju ,śpiewki” przy kołysce. J. Cieślikowski podkreśla, że „Tekstowi najprostszej usypianki ściagniętej do monotonnego zaśpiewu jednej samogłoski: a, a, a..., towarzyszył ruch ramion czy kołysanie kolebki. (...) Natomiast sam tekst usypiania pojawia się już jako akt ,upodmiotowienia" się dziecka i jest jedna z pierwszych form nawiazania uczuciowego, werbalnego kontaktu z dzieckiem"44.

Dźwiękowo-ruchowe - charakteryzują się wykonywaniem pewnej czynności przez osobę dorosła, której towarzyszy wydobywający się dźwięk: dziecko rozwija wtedy zmysły słuchu i wzroku; do tego typu można zaliczyć:

- brzakanie kluczami;

- „wydawanie dźwięku mokrym palcem wodzac po szybie”.

Ruchowe - polegaja na wprowadzeniu w ruch poszczególnych przedmiotów, aby w dziecku rozwinąć percepcję wzrokowo-ruchowa; do nich można zaklasyfikować:

- kręcenie naparstka;

- kręcenie kluczyka;

- kręcenie pieniadza.

Spośród gier i zabaw dzieci w okresie „niemowlęcym i dziecinnym” Golębiowski charakteryzuje $18^{45}$. Można je sklasyfikować według dwóch czynników. Pierwszy dotyczy osoby, która wykonuje, zarówno werbalne, jak i niewerbalne czynności zabawowe - czy jest to tylko dorosły, tylko dziecko, czy dziecko i dorosły. Drugi czynnik typizujący to rodzaje sposobu zabawy. Wśród nich można wyróżnić: słowne, ruchowe, słowno-ruchowe i manualne.

Na podstawie tych dwóch czynników można dokonać następującego ogólnego podziału zabaw okresu ",niemowlęcego i dziecinnego" zebranych przez Ł. Gołębiowskiego:

Słowne - obejmują tylko słowne zabawy, które miały m. in. rozszerzyć wiadomości dzieci; tekst jest wypowiadany tylko przez osobę dorosła, dziecko pozostawało bierne; zabawy te odbywały się w formie:

a) dialogu - do nich można zaliczyć:

- rozmowę z myszka:

„Myszko, Myszko! gdzieś była?
U Babci.
Coś jadła?
Ochłapki.

${ }^{39}$ Ł. Głębiowski, Gry $i$ zabawy..., s. 6.

40 Ibidem, s. 7.

${ }^{41}$ Ibidem, s. 188.

42. Ibidem, s. 7.

43 Ibidem, s. 6-7.

44 J. Cieslikowski, Wielka zabawa, Wroclaw 1985, s. 74.

${ }^{45}$ Wszystkie cytaty pochodza $z$ dzieła pt. Gry $i$ zabawy...; w nawiasach zostały podane strony cytowanych fragmentow. 
A czemuś nie przyniosła?

Bom zapominała"(9);

b) monologu - tutaj można zaliczyć:

- myszkę:

„Myszka, myszka poszła do laska,

Złapała ptaszka,

Nikomu go niedała

Sama go zjadła (10);

- maści kart - „,czterem chłopcom rozdaje się kolory kart, jeden będzie wino, drugi czerwień, trzeci dzwonek, czwarty żołądź; do każdego była przedmowa niańki; do pierwszego mówiła tak:

Wino, wino!

Daleko po ciebie jeżdżono do Węgier;

$\mathrm{Z}$ Węgier zaczepił o węgieł,

Postronki się urwały,

Konie padały

Hi przez pień" (11);

Ruchowe - do tych zabaw można zaklasyfikować wszystkie te, podczas których osoba bawiąca się, więc samo dziecko, sam dorosły lub dorosły i dziecko, wykonuje czynności ruchowe, bez użycia dodatkowych teksı́w słownych; można je podzielić, ze względu na wykorzystanie dodatkowego przedmiotu, na:

a) ruchowe bez użycia dodatkowego przedmiotu ${ }^{46}$ - te $\mathrm{z}$ kolei na czynności ruchowe wykonywane przez:

- samych dorosłych - do tych należa:

cienie - pokazuje się dziecku za pomoca palców na ścianie zajączka, gąskę, kapucyna itp. (10);

- samych dzieci - do tych należą:

król - taka nazwę nosiły dwie gry: „kładzie się ręka na ręce, choćby kilkorga dzieci, będąca na spodzie występuje na wierzch, i tak dalej przez kilka kolei, póki nareszcie znudzone ta jednostajnościa dzieci, nie wyrwą razem swych rączek, i nie postąpią do rozwiązania gry klepiąc się wzajemnie. Królem zowią także grę następujacą. Dziecko chowa twarz swoję, rękę na plecach kładzie, inne dzieci dotykaja się tej ręki, bijac i mocno czasem, kogo uderzony zgadnie, tego na miejscu swoim stawia" (11);

- dorosłych i dzieci - do tych należa:

hojdanem - ,jak pierwej na ręku, tak teraz na nóżce stojąc lubi dziecię";

b) ruchowe $\mathrm{z}$ użyciem dodatkowego przedmiotu - te także można podzielić w zależności od tego, kto wykonuje czynność:

- samo dziecko:

jeździec - zabawa ta przeznaczona była dla chłopczyka, który samotnie się bawił; „,byle, miał bicz i lada kijek już mu ów konik bryka, wierzga i niespokojnym się stawi, zacina go i powolnym być sobie zmusza, szczęśliwszy bez porównania, gdy polejcowawszy siostry, pogania je przed soba" (12);

ziele babka $-\mathrm{z}$ tej rośliny rosną na długich łodygach kwiaty ,tych urwać trzeba kilkanaście, podzielić się równo, i bić się niem i kto swoim kozakiem zetnie głowę u kozaka przeciwnika swego, ten ma prawo bić drugi raz jeszcze, przegrywa, kto co do jednego straci" (13);

cyga, bak - ,wydrażona to kula na pręciku u spodu przymocowana, w około którego sznurek okręcony; gdy się ta cyga albo bąk otwór u dzielnej na to rączki wsadzi, a rzemień lub sznurek odciagnie, raptem wyskakuje $\mathrm{i} \mathrm{z}$ nadaną sobie moca po podłodze się kręci $\mathrm{z}$ hukiem stopniowa gasnącym" (12 - 13);

- sam dorosły - Gołębiowski nic podaje takiego przykladu, ale opisuje zabawę, którą można zaklasyfikować zarówno do wykonywanych przez samego dorosłego, jak i samo dziecko, gdyż bańki puszczał najpierw sam dorosły, a dopiero potem dziecko:

${ }^{46}$ Pod hasłem ,dodatkowy przedmiot" rozumiem przedmiot, który slużyl do zabawy a niekoniecznie był on tylko zabawka, np. rzecz codziennego użytku. 
bulki mydlane - „dziecię bawi niańka, gdy wody mydlanej nabrawszy w słomkę, wydyma ja w bąble różnobarwne, każdy z nich odrywa się potem, ulatuje i znika, wkrótce i samo dziecię puszcza bańki, dziwi się im, zachwyca niemi, ściga nieprzenikając że i w dalszym życiu podobnież niejedna błyskotka zajmować go będzie, i uganiać się za nia przyjdzie mu chciwie, aż pokąd mniemana ich wartość w oczach jego nie zgaśnie" (10);

Słowno-ruchowe - do nich można zaliczyć zarówno te zabawy, przy których wykonywaniu oprócz czynności ruchowych, używane są także słowa; podział ten można uściślić wprowadzając jeszcze jeden element wspólny, jakim jest fakt, iż teksty słowne sa wykonywane przez doroslych, a czynności ruchowe zarówno przez dorosłych, jak i przez dziecko; do tej kategorii można zaliczyć:

- chowanie sie

stykanie się czota - polega na schylaniu główki dziecka na hasło: „baran, baran, tryk!” (8);

jazda wierzchowa - ,sadza się dziecka na kolanie i udaje jazdę na koniu stopniowo od wolnej po szybką mówiąc:

Jedzie Pan, Pan,

Na koniku sam, sam,

Jedzie żyd, żyd,

Hotata, hotata,

Jedzie chłop, chlop,

Z konika hop, hop" (9);

klaskanie - „tak njepewne jeszcze w małe rączęta, które tak cieszy rodziców. Pierwszy to dowód jakiegoś poznania i naśladownictwa"; przy klaskaniu także śpiewano:

„Koci, koci lapki,

Pojedziem do babki,

Da nam babka kaszki,

A dziadek okraski" (7);

stukanie - „małym paluszkiem w dłoń pulchna i podniesienie w górę rączki, w czasie kiedy piastunka mówi te slowa, pełne dowcipu:

Tu, tu kokoszka jagiełki warzyła,

W dziobek się sparzyła,

Temu dała, temu dała,

Tamtemu łepek urwała,

I het poleciała;

Do rzeczki..."(8);

dotyka się palcem dłoni dziecinnej, potem się go załechce, po rączce spieszno przebiegajac palcem i mówiąc:

„Biegla mysz,

Zjadła knysz,

Tu tu siadła,

Knysza zjadła" (9);

kowal - stukając w pięty mówi się:

„Kowalu, kowalu, podkuj mnie buty!

Poczekaj Mospanie

Niech ognia dostana

Stuk, stuk, stuk!" (9);

Manualne - w tych zabawach dzieci ćwiczyły zręczność oraz precyzje działania manipulując przedmiotami; do nich można zaliczyć:

budki z kart - „nagina się dwie karty ku sobie, szerzej u dołu postawione, tak, ażeby wierzchami oparte, utrzymały się nawzajem, i powstaja domki w ksztalcie namiotów: dla mamy (...) lada poruszenie te domki wali $\mathrm{z}$ niemala dziecięca radością, gdy za długo stoja, wywraca je umyślnie" (10); 
zolnierze - „zgięte w dlugości karty nieco odprostowane, stawiają się jeden przy drugim, czasem i w kilka rzędów, gdy szturchnie paluszkiem, wszyscy padaja, mniemani ci żołnierze" (10); tacki - to zabawa, która polegała na zrobieniu z kart sześcianów i innych figur (10).

Ł. Golębiowski podkreśla rolę zabaw dzieci uczacych się, nazywając je „studentskimi”: ,niechaj zabawy nie broni surowy dozorca lub nauczyciel, niechaj je wynajduje owszem, i sam te gry niewinne dzieli z nimi, a zarazem czuwa by przez plochość młodego wieku sobie lub drugim czego złego nie zrobiły. (...) Zbyt wcześnie zaprzęgamy je do pracy, zbyt ciagle, zbyt wiele może je uczemy, dajmyż im rosnąc, poszaleć, niechaj w nich krew nie drzymie, niech się żywość młodzicńcza nie gnębi"47. Nakazując im poszaleć optuje za autoteliczną funkcja zabawy.

Próbujac dokonać klasyfikacji gier studenckich Gołębiowskiego, należy zwrócić uwagę na dwie charakterystyczne cechy: pierwsza dotyczy gier ruchowych, w których zawsze jest używany jakiś przedmiot np. piłka, śnieżki, sznurek, itp., druga obejmuje gry umysłowe, skłaniajace dzieci do myślenia. Podkreślić należy, iż w tych grach, w przeciwieństwie do poprzednich, nie uczestniczą dorośli. Jest to już tylko zaczarowany świat bawiących się studentów.

Ruchowe - zawsze obejmują użycie jakiegoś konkretnego przedmiotu. Ze względu na cel tych gier można je podzielić na:

a) zręcznościowe - ich celem jest odpowiednie „wyrobienie" czynności zręcznościowych; można do nich zaliczyć:

W ścianę czyli łape - jeden z uczestników staje przed ściana ,,wtenczas każdy w ściankę uderza i piłkę łapie, kto ja zgubi, (...) kto upuścił sam do ściany idzic i bije go najpierw poprzednik jego, potem każdy, który piłkę złapie" (15);

skakanie - „skakano przez kij, trzymany sznurek, chustę, obręcz, przez rów” (19);

ślizganie - „, dorosłych to jest zabawa” (21); Gołębiowski opisuje powstanie łyżew: „Szczególniej podwiązana kostka większy dawala popęd ślizgającemu się, ztąd powstały udoskonaleniem późniejszem łyżwy" (12);

kregle - „na dobrze ubitej ziemi, lub usadzonej z drzewa takiej podstawie, jak tafla krzyżowa, szykuja się kręgle, stawiajac je na każdem dwóch prętów spojeniu, środkowe miejsce nieco wyższy król zajmuje, otacza go ośmiu poddanych..."; były to także zabawy nie tylko dzieci, ale i dorosłych (22);

b) rywalizujace - obejmuja wszystkie gry, których celem jest zdobycie nagrody, wygranie rywalizacji; do nich można zaliczyć:

bieganie do mety - ,starsi i młodsi i poważni dyrektorowie dzielili tę zabawę, której wiele życia, ruchu i wesołości; każdej, zwłaszcza majowej przechadzki była ozdoba" (20);

walka na kije - , ,aby uczestnicy nie uderzali się zbyt boleśnie słoma prosta zamiast kija opleciona, palcatami zwana, służyła do tego." (23);

forteca - zabawa polegała na obronie twierdzy: „dwóch rycerzy u bramy broniło twierdzy, 24 ja oblegało, bil żołnierzy nieprzyjacielskich obrońca warowni, gdzie tylko bez wsparcia samotnych potykał (...). Zwycięstwo następowalo wtenczas, gdy cała twierdza ludem nieprzyjacielskim zapełniona, załoga wyparta" (25);

rzucanie - Gołębiowski w Opisaniu historyczno-statystycznym miasta Warszawy zauważa: „Gdy uważam dokąd mam iść wprzódy, aż graią w piłkę; na drugiej lawie były kamienie żelazne, do tych ciskajac zrzucano je $\mathrm{z}$ ławy, ten co ostatni zrzuci, wygrywa"48.

c) zręcznościowo-rywalizujące - łącza w sobie zarówno element wygranej, jak i zręczność; można do nich zaliczyć:

- gry w piłkę - najbardziej ulubiona zabawa dziecinna; spośród charakteryzowanych przez Gołębiowskiego gier w piłkę można wyróżnić:

rozgrywajace się $w$ kole - koło podczas zabaw wyznaczało nie tylko obszar uczestników zabawy, ale także oddzielało bawiących się od reszty świata - miało więc cel praktyczny, jak i magiczny; do tych gier można zaliczyć:

${ }^{47}$ L. Golebbiowski, Gry $i$ zabawy..., s. 14.

48 E. Golębiowski, Opisanie historyczno-statyczne miasta Warszawy, Warszawa 1827, s. 33. 
w kasze - „stoja w koło, pierwszy w ziemię uderza, odbita piłkę kto zdobywa, łapie, a ten, co ja otrzymał, bijącemu w obie dłonie nadstawione zadaje razy, póki piłki nie zgubi, lub nie zemknie jej kto inny. Gdy schwyci piłkę bity, na jego miejscu idzie bijacy nia ostatni." (15);

podbijankę - wszyscy uczestnicy stoją w kole; jedna osoba rzuca w górę piłkę, pozostali ja podbijaja (18);

druzynowe - uczestnicy tworzyli dwie grupy zabawowe; celem gry było odniesienie zwycięstwa i walki z zasadami; do nich można zaliczyć:

w palanta - dzielono uczestników na dwie bandy i ,rzucano ku sobie piłkę nie już ręką lecz kijem w nia trafiajac" (17);

meta, pót mety - „dzielono się dwie duże gromady, odległość była wymierzona i polowa jej oznaczona. Kiedy silniejsi rzucali pilkę ku przeciwnej stronie, tamci złapać ja byli powinni. Wraz z rzuceniem piłki, ktoś wybiegał z młodszych, w całkowitej mecie o trzy kroki od przeciwników, wpół mety do połowy, nim wrócil, trzeba było go ugodzić, złapaną piłka. Jeśli trafiony, rannym się poczytywał, i już więcej do gry nie należal, chybiony do liczby zwycięzców przechodził..." - gra ta podobna jest do dzisiejszej gry „w dwa ognie”; (18);

żydek - gra „wyższej doskonałości”, składała się z 24 „różnych sztuk”- "od pierwszej, która była zręcznością i polegała na tym, że należało rzucić piłkę o podłogę w taki sposób, aby odbiła się o ścianę i dopiero ją złapać, poprzez kolejne: pod noga, pod ręka j o ścianę, liczenie palców jednej ręki, czyli na każdym kłaść piłkę, podrzucanie piłki jeden raz dłonią, drugi raz przewracając 40 razy ręką, po ostatni etap: „rzuca się pilkę o ścianę, żeby na głowę spadała i potem była złapaną". (17) Osoba, która wszystko wykonała poprawnie była nazywana królem;

- Śnieżki -zamiast piłek do zabawy używano kulek śniegu, którymi do siebie rzucano (20);

d) wytrzymałościowe - celem ich było „,wyrobienie” ducha odwagi; do nich można zaliczyć:

huśtawkę - Golębiowski przekazuje historię huśtawki oraz współczesne jemu udoskonalenie: „robiac wygodniejsze i bezpieczniejsze huśtawki, to poziomo, to pionowo ułożone, gdzie na czterech konikach siedząc lub krzesłach z poręczami, obracanych przez biegających około walca" (21-22);

e) naśladowanie - celem ich było odzwierciedlenie rzeczywistości, aby dorosłym życiu móc poprawnie pełnić odpowiednie role społeczne; zaliczyć do nich można:

musztrę - „zabawą była studentów, i mundury mieli swoje i choragwie, i bębny lub muzykę, broń drewniana oficerów, którzy ich doskonalili w obrotach" $(23)^{49}$.

Umysłowe - rozwijały przede wszystkim umysł dziecka; zaliczyć do nich można;

szubieniczke - gra, która dziš nazywa się „kólko i krzyżyk” (23), a pochodzi, jak twierdzi Gołębiowski, ,z dawnych czasów”;

tomi główke - na polu prostokata rysowano linie, które tworzyly figury, „odgadywać niektóre trudne bardzo, wprawia to młode głowy do kombinacyi matematycznych" (25);

Umysłowo-zręcznościowe - do nich zaliczyć można:

domino - gra miala takie same zasady jak dzisiejsze domino: „kto pierwszy postawił wszystkie swoje [kostki], ten wygrywa tyle punktów, ile komu liczb pozostało" (24).

kardynaly - ,,jednostajnej długości drewienka, odmiennie tylko wyrabiane, niejednostajnej liczby i różna wartość mające (...) skupiwszy w ręku lekko spuszczano, ten co był na ręku, piórkiem zakrzywionem rozmaicie wsparte drewienka tak podnosić musial, ażeby inne żadne nie drgnęło" (24).

Ł. Gołębiowski wśród gier dla studentów wyróżnia także takie, które uznaje za nierozsądne. Ze słów jego przebija troska: „Dobrze wychowany i rozsądny ich się nie imię, gbur i prostak tylko używa podobnych, słusznie więc za takowe psoty karany bywa" ${ }^{50}$. Do niestosownych gier zalicza: puszczanie po nosie chrabaszcza, dotykanie poślinionym palcem, paznokciem po twarzy, strzelanie z kluczów, ,,skręcony i zapalony papierek w nos wsadzić (26);

Ł. Gołębiowski dostrzega różnice w zabawach dziewcząt i chłopców. „Gry dziewczątek mniej szumne, nie tyle pociagajace za soba hałasu, więcej w nich spokojności dziewiczego wdzięku, lubej

\footnotetext{
${ }^{49}$ Por:: funkcja instrumentalna.

${ }^{50}$ Ł. Golębiowski, Gry $i$ zabawy, op. cit., s. 25.
} 
układności i chęci podobania się" "51. Spośród przedstawionych zabaw na uwagę zasługuja wyróżnione przez Gołębiowskiego przedmioty, jakimi bawiły się dziewczynki. Te przedmioty, które służyły zabawie można nazwać zabawkami. Podobnie, jak w przypadku określenia semantyki zabawy, tak i zdefiniowanie zabawki rodzi trudności. Według J. Bujaka za zabawkę będziemy uważać ,, przedmiot materialny specjalnie wykonany do celów zabawowych, który zawiera $w$ sobie treści kulturowe właściwej dla niego epoki..." 52 . R. Zięzio określa zabawki jako przedmioty, które „są kreowane przez bawiacego się bezpośrednio w trakcie zabawy" ${ }^{33}$. Dlatego w rękach bawiącego się dziecka ożywały przedmioty codziennego użytku, rośliny itp. ${ }^{54}$. Pomijając trudności teoretyczne, można dokonać krótkiego przeglądu zabaw dla dziewczą zebranych i opisanych przez Gołębiowskiego. Obejmują one trzy grupy zabaw:

1. Polegająe na naśladowaniu rzeczywistości - dziewczynki od najmłodszych już lat przygotowywały się do roli matki, żony, dlatego wśród zabaw spisanych przez Golębiowskiego, te naśladujące rzeczywistość są bardzo ważne;

- „Pierwszą zabawa chłopców konik i biczyk, pierwsza dziewcząt lalka, jak gdyby przeznaczenie swe zgadywała, z lalką się pieści, kołysze ja, przyśpiewuje jej, usypia, to ja hojda, to do łona swego przytula, daje piersi, w sukienkę ubiera i rozbiera, strofuje, czasem dawane sobie przestrogi do niej zwracając, ja ucząc, jak ma być dobra, żeby ja mama kochała i tatko" (26);

- zajmowanie się kuchnia - „łupiny z orzechów laskowych lub wloskich, spodek z żolędzi a tem lepiej sprzęt podobny drewniany posiada, trochę krup, chleba, wody, jabłko posiekane, służą do różnych przypraw, uczty wspaniałej, dobrego podwieczorku, a przynajmniej wybornej kawy" (27).

2. Zręcznościowe

- nawlekanie kwiatków - „nawleka jagody, paciorki perełki” (27);

- „wykoływanie deseniów, wycinanie, uciesza ja i zajmuje” (27);

- „trawki wiązanie - to plecenie wianków, aby się wróżba spelnila” (27);

- bukiet - polegała na pleceniu girlandów, wianeczków na wesele (27);

- do pary i nie do pary - „w tę grę wszędzie grać można, i cokolwiek do niej użyć, orzechy, cukierki, groch; bo idzie o to jedynie, aźeby zgadnąć i odpowiedzieć na zapytanie" (28).

3. Ruchowe

- „samotna się nie znudzi (...), biega od kącika do kącika, w każdym coś szczebiocze, każdemu coś, jak gdyby przyjaciółce swej, powierza, i ubawi się wyśmienicie" (27);

- taniec - „kaźda z młodziutkich panienek już lubi taniec, wie, że się w nim pięknie okazać zdoła. Czyli go umie, lub nie? Już sił swych doświadcza, kiedy istotnych nie można pląsów, przynajmniej zajączka wyskoczyć rada" (28).

W Grach i zabawach pogrupowanych jest około 50 zabaw dla dzieci. Wśród nich są także takie, które zostały przyjęte przez dorosłych. Gołębiowski nie tylko w tym miejscu i w ten sposób omawia zabawy dziecięce. Opisując zabawy dorosłych informuje, iż także dzieci się w nie bawiły. Wśród adaptacji dziecięcych należy wyróżnić:

- noska - zasady gry podobne do gry w bicza - gry w karty; podobna do marynarza „W tem była różna, że ile kto miał więcej zabitych, tyle razy przegrywajacego uderzył kartą po nosie" (45);

- drużbarte - „g gra niższych klas lub dzieci w karty; kolory tylko idą starszeństwem raz oznaczonem stale" (45);

- czadz - ,to rzucanie orzechów dzieciom, albo i pieniędzy, upominek to był z zabawa złączony, zajmowało starszych patrzeć, jak się o nie ubiegały" (63);

- żurawkę - Gołębiowski wspomina o niej na podstawie Dworzanina Ł. Górnickiego dodając, iż „teraz już [jej] nie umiemy" (63);

\footnotetext{
sI Ibidem, s. 26.

52 Cyt. za: R. Zięzio, op. cit., s. 10.

53 lbidem, s. 10.

${ }^{54}$ Por. dokładne zasady klasyfikacji zabawek dokonal R. Zięzio w cytowanej pracy.
} 
- krag - „dwie grupy chłopców z kijami w rękach wybierają sobie miejsce na placu i zaznaczaja sobie kręgiem pole. Przeciwna drużyna koniecznie chce wytoczyć za metę" (64);

- bjerki - sam Gołębiowski zauważa, że ta gra jest poważniejsza „lubo także od wiejskich najwięcej używana dzieci"; polega na tym, iż dzieci same robią z kory figurki nadając im nazwiska np. króla, ekonoma, pana parobka itp.; potem stojąc blisko, biora je na rękę i kto złapie najznakomitszą personę, ten wygrywa; (64);

- prawdę/fałsz - jedna osoba kładzie dwa palce na stół i mówi np. wół ma rogi, krowa ma rogi itd.; pozostałe osoby trzymaja palce na stole zawsze, gdy osoba prowadząca mówi prawdę; jeżeli ktoś się pomyli daje fant;

- zielone - zabawa trwała od drugiego dnia Wielkanocy do świętego Michała. Osoby umawiały się, że przez ten okres będa nosiły przy sobie coś zielonego. „Gra to dzieci, przyjaźni, miłości, mogąca dawać sobie sposobność robienia upominku" (85);

- śmieszka - zabawa polegała na tym, aby jak najdłużcj powstrzymać się od śmiechu.

Gołębiowski podkreślał wartość gier umysłowych, które są ,wyższych społeczeństw oznaka i dla młodzieży szlachetniejsze wielce przydatne" ${ }^{55}$. Młodzież brała także udział $w$ kuligach i majówkach. „W tym czasie uczniowie obchodzili majówki, czyli rekreacye majowe; w wilia nie było lekcji, bo przygotować się musieli na tę uroczystość lubą Nazajutrz, zwykle 1. Maja, lub później (...) uszykowani w rzędy pod choragwiami swemi, wraz z dyrektorami i nauczycielami szli do wioski o milę, lub dalej, gdzie ochoczy gospodarz (...) częstował wszystkich z radością (...). Gra w piłkę, bieganie, huśtawka, przebieranie się w wojskowe ubiory, sprawialy radość powszechna"

Dzieci bawią się także podczas różnych świąt, np. „Mają one [grzechotki] poczatek w W. czwartek, koniec w W. sobotę, trwaja przez ten czas, kiedy kościół nie używa dzwonów, tylko klekotek go kołatania. Jak to na wieźy kościelnej przedtem odezwała się klekota, chłopcy natychmiast nie omieszkali biegać po ulicach ze swojemi grzechotkami, czyniąc niemi przykry hałas" ${ }^{57}$. Te i inne zabawy przyjęte od dorosłych przez dzieci opisuje Gołębiowski w swoich dziełach. A jak się bawili dorośli? Ich zabawom poświęcił Gołębiowski więcej uwagi nie tylko w Grach $i$ zabawach, ale i w piśmie pt. Lud polski, jego zwyczaje i zabawy, dzieląc je według regionu, stanu, majątku, pozycji. Łaczył je przede wszystkim z obchodami świąt, nie tylko kościelnych (m. innymi Bożym Narodzeniem, Zielonymi Świątkami, Wielkanoca), ale i świeckich (np. puszczaniem wianków).

Konkludujac: „Zabawa łączy i dzieli. Przykuwa. Urzeka, czyli oczarowuje, pelna jest najszlachetniejszych wlasności, jakie człowiek potrafi w przedmiotach dostrzec i wyrazić"58. Wlaśnie Lukasz Gołębiowski, jako pierwszy wyodrębnił zabawowy folklor dziecięcy i mlodzieżowy, spróbowal ukazać słowami ,nieokreślony”, magiczny krąg zabaw i zabawek. I choć brak mu krytycyzmu $\mathrm{i}$ oryginalności $\mathrm{w}$ przedstawieniu zgromadzonego materiału, to trzeba docenić zebranie i opisanie tak dużych ilości zabaw dorosłych, w tym także, a właściwie przede wszystkim, zabaw i zabawek dziecięcych oraz pamiętać o Gołębiowskim jako pionierze przecierającym szlaki w polskich badaniach etnograficznych nad zabawami. Nam, mieszkańcom globalnej, skomputeryzowanej wioski pozostaje sięganie do źródeł, aby podtrzymywać tradycję przekazując stare, ale potrzebne także na początku XXI wieku ,baran, baran, tryk!”. Każde dziecko potrzebuje zabawki, ale nade wszystko osoby, która wejdzie $\mathrm{z}$ nim $\mathrm{w}$ zaczarowany świat zabawy.

\footnotetext{
${ }^{55}$ Ł. Golębiowski, Gry $i$ zabawy, op. cit., s. 90 .

56 Ibidem, s. 86.

37 Ibidem, s. 279

${ }^{58}$ Cyt. za: U. Kaczmarek, op. cit.
} 